Saudi Journal of Medicine

Abbreviated Key Title: Saudi J Med ISSN 2518-3389 (Print) |ISSN 2518-3397 (Online)

\title{
Across The Courses and Years: The Course Evaluation of E-Learning in Medical Education. A Cross-Sectional Study
}

\author{
Qurrat-ul-ain Leghari ${ }^{1}$, Rabia Akram ${ }^{2}$, Nooria Naeem ${ }^{3}$, Rubina Kausar ${ }^{4}$, Muhammad Akhlaq ${ }^{5}$, Saba Iqbal ${ }^{6 *}$ \\ ${ }^{1}$ Senior Demonstrator Physiology, University College of Medicine \& Detansary, Lahore, Pakistan \\ ${ }^{2}$ Assistant Professor in Gynea \& Obst, Shalamar institute of health sciences, Lahore, Pakistan \\ ${ }^{3}$ Demonstrator Physiology, University College of Medicine \& Detansary, Lahore, Pakistan \\ ${ }^{4}$ Lecturer in Islamic studies, University College of Medicine \& Detansary, Lahore, Pakistan \\ ${ }^{5}$ Professor ENT, Pak Red Crescent Medical College, Dina Nath, Kasur, Punjab, Pakistan \\ ${ }^{6}$ Assistant Professor, Medical Education, Pak Red Crescent Medical College, Dina Nath, Kasur, Punjab, Pakistan
}

DOI: $10.36348 /$ sjm.2020.v05i12.003

| Received: 21.11.2020 | Accepted: 03.12.2020 | Published: 07.12.2020

*Corresponding Author: Saba Iqbal

\section{Abstract}

Program Evaluation is the systematic gathering of information for purposes of making decisions. After the development and establishment of e learning program, Pak Red Crescent Medical \& Dental College (PRCM\&DC) were made with the help of the Medical Education Department a program evaluation questionnaire based on all frequently asked questions send to all students by e evaluation form. All the students who have The Students who have internet facility and attend the classes regularly are included. Student's response rate is $34.88 \%$. Reliability coefficient of the questionnaire is 0.822 . Majority of the students found the clear objectives of the subject and interactive teaching decrease the anxity. Students were satisfied with learning material which is provided by the facilitators like lesson plans, course notes, handouts books and important notes are very helpful. Many students agreed that they were encouraged to asked questions and give answers during lectures, and most of them were satisfied with the delivery and pace of lecture. Majority of the students were satisfied with the present teaching through e learning method. They were well understood the teaching and learning material and also were appreciate the organization of the thought material.

Keywords: Course Program, e Learning, Medical Education, Course Evaluation.

Copyright (0) 2020 The Author(s): This is an open-access article distributed under the terms of the Creative Commons Attribution 4.0 International License (CC BY-NC 4.0) which permits unrestricted use, distribution, and reproduction in any medium for non-commercial use provided the original author and source are credited.

\section{INTRODUCTION}

Meaningful documented input from students is essential for the improvement of courses and one of the most common indirect course assessment methods is the course evaluation survey. During the Covid 19 pandemic, when we are shifted $15 \%$ to $100 \%$ on online teaching. These surveys providing us Student feedback which has been considered to be an effective and informative tool for improvement, modification and up gradation of undergraduate courses. In an era of accountability, students face an overwhelming burden of dispersed knowledge and desperately select for repetition and memorization rather than understanding [1]. This e-questionnaire allows the students to reflect and provide feedback on their learning and making basic as well as clinical subjects more interesting and practicable [2].

Many studies show that students learn best when learning objectives and learning outcomes are well identified, teacher is capable of related to each other and allied to real-life examples [3]. Learning can thus be facilitated in our medical schools by integration of knowledge in basic and applied subjects with eradication of minor details [4]. During covid, we are shifted from partial to $100 \%$ from face to face class to virtual classes and e-learning only source of update knowledge, not skill nor attitude and it is a time to experiment the possible future changes in traditional curriculum, many medical colleges in first two and a half years we taught basic sciences subjects like Anatomy, Physiology, Pharmacology, Pathology etc. In this study, first and second year medical students evaluated their basic science subjects on multiple common items [5].

\section{AIM \& OBJECTIVES}

- To find out the progress of the program

- To identify the problems

- To utilized the available resources

- To ensure that current and future curriculum changes meet program goals and objectives

- To collect the fundamental information for future evaluation and planning 


\section{METHOD}

They were given questionnaire, based on frequently asked questions by the students during the establishment of the e-learning program. This was a cross-sectional descriptive analytic study, which was conducted in 2020 during the covid 19 pandemic, at the Pak Red Crescent Medical and Dental College, Dina Nath. Subjects were medical students during their medical education (from first to final year MBBS). Both genders were recruited as respondents in this study. The course evaluation at this college is webbased: after half completed course, students receive an invitation by Whatsapp massage to evaluate online all subjects for which they part took in the examination. Since the academic calendar ends in January, this means that course evaluations for the first term take place during the second term.

Total number of medical students in first year 100 students, second year 100 and third year 90 students in forth year 36 students and in final year 18 students, The calculated sample size was 121. After explaining the study design and objectives on zoom meeting, we obtained students' verbal consent. This study was approved by the medical education committee (the Pak Red crescent Medical and Dental College).

We used a questionnaire having two parts. In first part, the students recorded their gender, the living state (day scholar or hostilities), study year and marital status. And second part, based on 22 questions on 5point Likert scale over the elements that we considered as affective factors on medical education in different domains like learning outcome, classroom environment, teaching and learning methodologies, assessment methods and program feedback etc., were those which were considered as the most important elements of medical education. The statistical package for the social sciences (SPSS version 24) was used for statistical analysis. The relation between satisfaction of professional teaching, bedside teaching, theoretical education and variables was analyzed by chi square. Manthel Haenzel Chi square was computed whenever indicated. $\mathrm{P}$ values equal to or less than $5 \%$ were considered significant.
Inclusive Criteria: All the students who are attending the online classes and they have good internet service at their places

Exclusive Criteria: All the students who have internet connectivity issues and they are unable to attend online classes.

\section{RESULTS}

The participants of this study were the first to final-year medical students at the Pak Red crescent Medical and Dental College, Dina Nath during 20192020. The first and second year class comprised 56 students and the third year class 41 students forth year 25 students and final year 12 year (total students are 344). 120 students give the response out of that only 105 fill complete Performa, so our response rate is $34.88 \%$.

Reliability Analysis is an important concept in applied research. The reliability analysis has shown that there are 22 items was used for program evaluation in medical students. Value of cronbach's Alpha was 0.822 . It is also called reliability coefficient. It is a simple rule in the description of the reliability coefficient that higher the value higher will be there liability of data [6]. Gender distribution showed female preponderance $62(56.4 \%)$ and male $43(39.1 \%)$. The table no III has shown that correlation coefficient value is 0.067 which is away from 1 which shows no any positive relationship between students gender and status that is either they live in their homes or in boarding.

\section{Responces Rate}

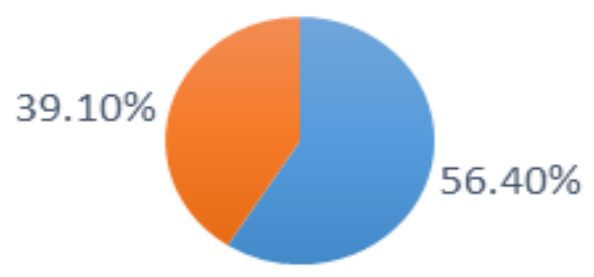

females males

Fig-1: Gender based distribution of responces

Table-1: items reliability coefficient

\begin{tabular}{|l|l|l|}
\hline Cronbach's Alpha & Cronbach's Alpha Based on Standardized Items & N of Items \\
\hline .628 & .822 & 22 \\
\hline
\end{tabular}


Table-2: Study characteristics of 22 included studies describing an e-learning program evaluation

\begin{tabular}{|c|c|c|c|c|c|c|c|}
\hline S/No & Items & $\begin{array}{l}\text { Strongly } \\
\text { Agree }\end{array}$ & Agree & Neutral & Disagree & $\begin{array}{l}\text { Strongly } \\
\text { Disagree }\end{array}$ & $\begin{array}{l}\text { Cronbach's } \\
\text { Alpha }\end{array}$ \\
\hline 1 & $\begin{array}{l}\text { The learning outcomes \& course } \\
\text { objectives were clear }\end{array}$ & $10(9.1 \%)$ & $37(35.2 \%)$ & $25(22.7 \%)$ & $22(21 \%)$ & $11(10.5 \%)$ & .608 \\
\hline 2 & $\begin{array}{l}\text { The course workload is } \\
\text { measurable }\end{array}$ & $8(7.6 \%)$ & $31(29.5 \%)$ & $24(22.9 \%)$ & $24(22.9 \%)$ & $18(17.1 \%)$ & .611 \\
\hline 3 & The course well organized & $7(6.7 \%)$ & $33(31.4 \%)$ & $31(29.5 \%)$ & $25(23.8 \%)$ & $9(8.6 \%)$ & .613 \\
\hline 4 & $\begin{array}{l}\text { To Participate actively in the } \\
\text { course }\end{array}$ & $25(23.8 \%)$ & $48(45.7 \%)$ & $20(19.0 \%)$ & $6(5.7 \%)$ & $6(5.7 \%)$ & .624 \\
\hline 5 & $\begin{array}{l}\text { To you think you have made } \\
\text { progress in this course }\end{array}$ & $7(6.7 \%)$ & $44(41.9 \%)$ & $20(19.0 \%)$ & $26(24.8 \%)$ & $8(7.6 \%)$ & .610 \\
\hline 6 & $\begin{array}{l}\text { Approximate level of your own } \\
\text { attendance during the whole } \\
\text { course }\end{array}$ & $3(2.9 \%)$ & $8(7.6 \%)$ & $25(23.8 \%)$ & $41(73.3 \%)$ & $28(26.7 \%)$ & .646 \\
\hline 7 & $\begin{array}{l}\text { The course was well structured to } \\
\text { achieve the learning outcomes }\end{array}$ & $7(6.7 \%)$ & $40(38.1 \%)$ & $21(20.0 \%)$ & $25(23.8 \%)$ & $12(11.4 \%)$ & .603 \\
\hline 8 & $\begin{array}{l}\text { The learning and teaching } \\
\text { methods encouraged your } \\
\text { participation }\end{array}$ & $9(8.6 \%)$ & $44(41.9 \%)$ & $23(21.9 \%)$ & $16(15.2 \%)$ & $13(12.4 \%)$ & .618 \\
\hline 9 & $\begin{array}{l}\text { The overall environment in the } \\
\text { class was conductive to learning }\end{array}$ & $9(8.6 \%)$ & $41(39 \%)$ & $26(24.8 \%)$ & $22(21.0 \%)$ & $7(6.7 \%)$ & .613 \\
\hline 10 & Classrooms were satisfactory & $10(9.5 \%)$ & $50(47.6 \%)$ & $25(23.8 \%)$ & $10(9.5 \%)$ & $10(9.5 \%)$ & .601 \\
\hline 11 & $\begin{array}{l}\text { Learning materials (lesson plans, } \\
\text { course notes and handouts etc) } \\
\text { were relative and useful }\end{array}$ & $10(9.5 \%)$ & $48(45.7 \%)$ & $25(23.8 \%)$ & $13(12.4 \%)$ & $9(8.6 \%)$ & .616 \\
\hline 12 & $\begin{array}{l}\text { Recommended reading books etc } \\
\text { were relevant and appropriate }\end{array}$ & $10(9.5 \%)$ & $71(67.6 \%)$ & $17(16.2 \%)$ & $6(5.7 \%)$ & $1(1.0 \%)$ & .613 \\
\hline 13 & $\begin{array}{l}\text { The provision of learning } \\
\text { resources in the library was } \\
\text { adequate and appropriate }\end{array}$ & $7(6.7 \%)$ & $45(42.9 \%)$ & $33(31.4 \%)$ & $16(15.2 \%)$ & $4(3.8 \%)$ & .612 \\
\hline 14 & $\begin{array}{l}\text { The provision of online learning } \\
\text { resources was adequate and } \\
\text { appropriate }\end{array}$ & $8(7.6 \%)$ & $33(31.4 \%)$ & $18(17.1 \%)$ & $25(23.0 \%)$ & $21(20.0 \%)$ & .594 \\
\hline 15 & $\begin{array}{l}\text { The pace of the course was } \\
\text { appropriate }\end{array}$ & $4(3.8 \%)$ & $39(37.1 \%)$ & $30(28.6 \%)$ & $22(21.0 \%)$ & $10(9.5 \%)$ & .596 \\
\hline 16 & $\begin{array}{l}\text { The ideas and concepts were } \\
\text { presented clearly }\end{array}$ & $5(4.8 \%)$ & $42(40.0 \%)$ & $31(29.5 \%)$ & $15(14.3 \%)$ & $12(11.4 \%)$ & .599 \\
\hline 17 & $\begin{array}{l}\text { The method of assessment were } \\
\text { reasonable }\end{array}$ & $4(3.8 \%)$ & $44(41.9 \%)$ & $29(27.6 \%)$ & $11(10.5 \%)$ & $17(16.2 \%)$ & .597 \\
\hline 18 & $\begin{array}{l}\text { Feedback on assessment was } \\
\text { timely }\end{array}$ & $5(4.8 \%)$ & $42(40.0 \%)$ & $31(29.5 \%)$ & $15(14.3 \%)$ & $12(11.4 \%)$ & .666 \\
\hline 19 & $\begin{array}{l}\text { Feedback on assessment was } \\
\text { helpful }\end{array}$ & $4(3.8 \%)$ & $50(47.6 \%)$ & $28(26.7 \%)$ & $13(12.4 \%)$ & $9(8.6 \%)$ & .597 \\
\hline 20 & You understood the lectures & $5(4.8 \%)$ & $39(37.1 \%)$ & $22(21.0 \%)$ & $26(24.8 \%)$ & $1(1.0 \%)$ & .610 \\
\hline 21 & The material was well organized & $4(3.8 \%)$ & $55(52.4 \%)$ & $27(25.7 \%)$ & $11(10.5 \%)$ & $8(7.6 \%)$ & .618 \\
\hline 22 & $\begin{array}{l}\text { The lecture was responsive to } \\
\text { student need and problems }\end{array}$ & $3(2.9 \%)$ & $43(41.0 \%)$ & $32(30.5 \%)$ & $16(15.2 \%)$ & $10(9.5 \%)$ & .728 \\
\hline
\end{tabular}

Table-3: Correlation between gender and status Correlations

\begin{tabular}{|l|l|l|l|}
\hline \multicolumn{2}{|c|}{ Correlations } & Gender & Status \\
\hline \multirow{3}{*}{ Gender } & Pearson Correlation & 1 & .067 \\
\cline { 2 - 4 } & Sig. (2-tailed) & & .496 \\
\cline { 2 - 4 } & $\mathrm{N}$ & 105 & 105 \\
\hline \multirow{3}{*}{ Status } & Pearson Correlation & .067 & 1 \\
\cline { 2 - 4 } & Sig. (2-tailed) & .496 & \\
\cline { 2 - 4 } & $\mathrm{N}$ & 105 & 105 \\
\hline
\end{tabular}

\section{DISCUSSION}

Program evaluation is a process of making judgment about the extent to which a particular educational program achieved its objectives [7] and is also measuring the extent to which a program delivered is effective and efficient in full filling its intended purpose of its development or creation. Feedback from the students is a reasonably accurate and most reliable way to test the teaching and learning process and its efficacy [2, 8]. By E Questionnaire forms, it is also very comfortable, affordable and easy to procure.

A lot of researches have been conducted to find out the response rate of students. Some scholors think that it depends upon the students themselves. When we compared the academic performance of the boarder and day scholar students responses [9]. The majority of the participants were male students. In general, the majority of students who participated in 
this research expressed a positive perception of the teaching and learning during online teaching [2]. In this study we found no any correlation between gender and living status of the students Mengel et al., found the almost same results in their study [10].

In present study $44.3 \%$ students are in favor with the written learning objectives and outcomes before starting the class because it reduce the risk of wasting the time as well as stress and anxiety of the students [11]. Initially students feel, depression, stress and anxiety during medical course, will influence on performance and after that, they become well organized with their course as the results shows first 2 years years students feel more burden of study as compare to remaining 3 years students, about $40 \%$ students are feel the course workload is more, only $22.9 \%$ are neutral and $37 \%$ students feel no course work load for them $[12,13]$. Many studies shows, active learning is more powerful for life long memory than deductive, $69.5 \%$ students wants to learn the course through active learning while only $12 \%$ wants deductive lectures [14]. Many studies has discovere beneficial view as to what encouragethe students to express in tutorials as well as in classroom. With this understanding, the facilitators can plan different strategies and apply proper techniques to create aninteractive classroom [15]. As results shows in present study, 50.5\% students were agree on it, $21.9 \%$ students were neutral and $27.6 \%$ were not agree. Althought it is difficult to assess the medical students from online assessment because by this we only assess the knowledge nither skill nor attitude [16], that's way only $48 \%$ appreciate the assessment methodology, only 57\% students are not satisfy with assessment methodology. The results are full endorse the research held in Samara University [17]. Timely Feedback on assessment was helpful for study 54\% student are appreciate it and only 9\% students are not like assement feedback sysem [18].

\section{CONCLUSION}

\section{Limitations of the Study}

We also recognize that student course evaluations have their limitations. Although highly reliable, the quantitative ratings in this study were based on cognation, not skills nor attitude. Another limitation is that courses may need to include material for which students may not see the instant assessment, teaching material that may not be rated highly even if well organized and delivered.

\section{Recommendations of the study}

Experienced and well trained educators need to include what is professionally valuable rather than automatically defer to student approval. However, there seems to be little question that well organized content and delivery is valuable in learning and is furthermore rewarded with high quality ratings by student
Declaration of interest: The authors report no conflicts of interest. The authors alone are responsible for the content and writing of the article.

Acknowledgements: The authors would like to thank the students of Pak Red Crescent Medical \& Dental College

\section{REFERENCES}

1. Barteit, S., Guzek, D., Jahn, A., Bärnighausen, T., Jorge, M. M., \& Neuhann, F. (2020). Evaluation of e-learning for medical education in low-and middle-income countries: A systematic review. Computers \& Education, 145, 103726.

2. Abdulghani, M. A., \& Al-Naggar, R. A. (2015). Students' perceptions about learning pharmacology at a single private institute in Malaysia. Journal of Taibah University Medical Sciences, 10(1), 40-44.

3. Harden, R. M. (2002). Learning outcomes and instructional objectives: is there a difference?. Medical teacher, 24(2), 151-155.

4. Sadoski, M., \& Sanders, C. W. (2007). Student course evaluations: common themes across courses and years. Medical Education Online, 12(1), 4463.

5. Badyal, D. K., \& Singh, T. (2015). Teaching of the basic sciences in medicine: Changing trends. Natl Med J India, 28(3), 137-40.

6. Gliem, J. A., \& Gliem, R. R. (2003). Calculating, interpreting, and reporting Cronbach's alpha reliability coefficient for Likert-type scales. Midwest Research-to-Practice Conference in Adult, Continuing, and Community Education.

7. Zajano, N. C., \& Stalford, C. B. (1984). Educational Evaluation. Am J Eval. 5(1):56-57.

8. Abrami, P. C., d'Apollonia, S., \& Rosenfield, S. (2007). The dimensionality of student ratings of instruction: What we know and what we do not. In The scholarship of teaching and learning in higher education: An evidence-based perspective (pp. 385-456). Springer, Dordrecht.

9. Faisal, R., Shinwari, L., \& Izzat, S. (2016). Academic performance of day scholars versus boarders in pharmacology examinations of a medical school in Pakistan. J Pak Med Assoc, 66(9), 1094-97.

10. Mengel, F., Zölitz, U., \& Mengel, F. (2017). Gender Bias in Teaching Evaluations Gender Bias in Teaching Evaluations. J Eur Econ Assoc. 17(2):535-66. Available from: https://www.econstor.eu/bitstream/10419/170984/ 1/dp11000.pdf

11. Mahajan, M., \& Singh, M. K. S. (2017). Importance and benefits of learning outcomes. IOSR Journal of Humanities and Social Science, 22(03), 65-67.

12. Restuputri, D. P., Pangesti, A. K., \& Garside, A. K. (2019). The measurement of Physical 
Workload and Mental Workload Level of Medical Personnel. Jurnal Teknik Industri. 20, 34.

13. Siddique, A., Iqbal, S., Arooj, M., \& Chaudhry, S. (2012). Gender Difference in Perceived Mental Stress Among First Year Medical Students. Proceeding SZPGMI Vol, 26(1), 57-60.

14. Zijdenbos, I., Fick, T., \& Cate, O. T. (2011). How we offer all medical students training in basic teaching skills. Medical Teacher, 33(1), 24-26.

15. Abdullah, M. Y., Bakar, N. R. A., \& Mahbob, M. H. (2012). Student's participation in classroom: What motivates them to speak up?. ProcediaSocial and Behavioral Sciences, 51, 516-522.

16. Weleschuk, A. (2019). Online Assessment in Higher Education. Taylor Institute for Teaching and Learning Guide Series. Calgary, AB Taylor Inst Teach Learn Univ Calgary. 2019; Available from:

http://taylorinstitute.ucalgary.ca/resources/guides

17. Debele, E. T., \& Kelbisa, E. M. (2017). The role of active learning methods for classroom participation: the case of first year students of sociology in Samara University. IOSR Journal of Humanities and Social Science, 22(7):11-18.

18. Özden, M. Y. (2005). Students' perceptions of online assessment: A case study. International Journal of E-Learning \& Distance Education/Revue internationale du e-learning et la formation à distance, 19(2), 77-92. 